\title{
Spectrolebias brousseaui (Cyprinodontiformes: Rivulidae: Cynolebiatinae), a new annual fish from the upper río Mamoré basin, Bolivia
}

\author{
Dalton Tavares Bressane Nielsen
}

Spectrolebias brousseaui is described from a temporary pool from the upper río Mamoré basin, Departamento Santa Cruz, Bolivia. The new species is distinguished from all congeners, by the overall dark blue coloration on the posterior two-thirds of body with bright blue iridescent spots vertically aligned in males. Spectrolebias brousseaui differs from all other species of the genus, except $S$. filamentosus, for having pelvic fins separated by a space ( $v s$. pelvic fins in contact), long filaments at the tip of the dorsal and anal fins in males (vs. absence of filaments or presence only on dorsal fin in S. semiocellatus and $S$. inaequipinnatus, or the presence on the anal fin in S. chacoensis), and presence of contact organs on the scales of the flanks in males (vs. absence of contact organs on flanks in all remaining Spectrolebias species).

Spectrolebias brousseaui é descrita de uma poça temporária localizada na região superior da bacia do río Mamoré, departamento de Santa Cruz, Bolívia. A espécie nova distingue-se de todos os congêneres pelo padrão de cor azul escuro nos dois terços posteriores do corpo com pontos azuis claros iridescentes alinhados verticalmente em machos. Spectrolebias brousseaui difere das outras espécies do gênero, exceto S. filamentosus, por ter as nadadeiras pélvicas separadas por um espaço ( $v S$. nadadeira pélvicas juntas), longos filamentos nas extremidades das nadadeiras dorsal e anal em machos (vs. ausência de filamentos ou a presença apenas na nadadeira dorsal em S. semiocellatus e S. inaequipinnatus, ou pela presença de filamentos na nadadeira anal em S. chacoensis), e presença de órgão de contato nas escamas do flanco em machos (vs. ausência).

Key words: Phylogeny, Spectrolebias filamentosus, Synapomorphies, Temporary pool.

\section{Introduction}

The systematics of Spectrolebias Costa \& Nielsen, 1997 has substantially changed in the last few years (Costa 1998, 2006, 2007, and 2010). The first nominal species of Spectrolebias, S. semiocellatus was described by Costa \& Nielsen, 1997. Costa (1998) believed that the genus has only one species, Spectrolebias semiocellatus. Costa $(2006,2007)$ relocated Spectrolebias as a subgenus of Simpsonichthys and considered five valid species within the subgenus Spectrolebias: S. chacoensis (Amato, 1986), from the río Paraguai basin, in Paraguay and Argentina; S. costai (Lazara, 1991) from the rio Tocantins-Araguaia basin; S. semiocellatus Costa \& Nielsen, 1997 from the rio Araguaia basin; $S$. filamentosus (Costa et al.,1997), from the río Madeira basin, in Bolivia; S. reticulatus (Costa \& Nielsen, 2003), from the rio Xingu basin. An additional species, S. inaequipinnatus, was described by Costa \& Brasil (2008) from the rio Tocantins basin . Two years later, Costa (2010) revalidated Spectrolebias in the category of genus again totaling six valid species.
The genus Spectrolebias is distributed on river drainages along the right margin of the Amazon River. All species of the genus Spectrolebias are considered annual fish for living in temporary habitats and resisting desiccation by laying their eggs on the substratum. Annual fish are unique in the fact that their eggs develop very slowly and can go through up to three diapauses, depending on genetic and environmental factors (Myers, 1952; Wourms, 1972).

According to Costa (2006), Spectrolebias is distinguished from all other cynolebiasins by two unambiguous synapomorphies: a long hyomandibular and a narrow proximal tip of the fourth ceratobranchial.

A new species of Spectrolebias was discovered in the upper río Mamoré basin, Bolivia. The specimens were collected in a small seasonal temporary pool, distant about $370 \mathrm{~km}$ from the type locality of Spectrolebias filamentosus being, therefore the second species found in Bolivia, from the upper río Mamoré. This new species is described herein.

Universidade de Taubaté, Laboratório de Zoologia, Departamento de Biologia. Praça Marcelino Monteiro 63, 12030-010 Taubaté, São Paulo, Brazil.dnielsen@uol.com.br 


\section{Material and Methods}

Measurements were taken point-to-point under a stereomicroscope with digital calipers to the nearest $0.1 \mathrm{~mm}$ on the left side of the specimen following Costa $(1995 ; 2007)$. Measurements are expressed as percents of standard length (SL), except the measurement of the head, which are recorded as percents of head length (HL).

In the description, each count is followed by its frequency in parentheses. Frontal squamation nomenclature follows Hoedeman (1958) and Costa (2006). Institutional abbreviations are MZUSP: Museu de Zoologia, Universidade de São Paulo, São Paulo and MNKP: Museo Noel Kempff, Santa Cruz de La Sierra, Bolivia.

\section{Spectrolebias brousseaui, new species Figs. 1-2}

Holotype. MNKP 10162, male, $28.4 \mathrm{~mm}$ SL, Bolivia, Departamento Santa Cruz, $47.5 \mathrm{~km}$ north of San José dos Chiquitos, pool near of río San Pablo, tributary of río Mamoré, 17²5’31'S 6040'44”W, 19 Apr 2008, R. D. Brousseau.

Paratypes. MZUSP 109219, 1 male and 2 female, 25.3-28.7 mm SL, collected with the holotype. MNKP 10163, 3 females, 26.7$34.6 \mathrm{~mm}$ SL collected with the holotype.

Diagnosis. The new species differs from the remaining representatives of the genus Spectrolebias, by the unique color pattern of males, viz., anterior third of body light brown, posterior two-thirds of body dark blue, almost black in the dorsal region, with rows of bright blue spots, relatively large size, with about half the diameter of the pupil. Spectrolebias brousseaui distinguished from all congeners except $S$. filamentosus, by having pelvic-fin bases separated by an interspace ( $v s$. pelvic-fin bases in contact), long filamentous rays on the tip of dorsal and anal fins in males ( $v s$. absence of

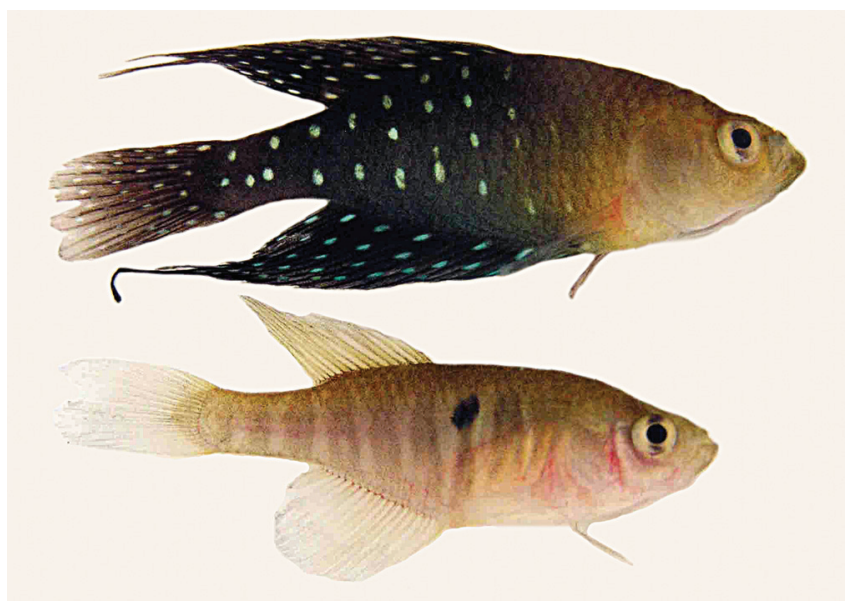

Fig. 1. Spectrolebias brousseaui, male (above), holotype, MNKP 10162, $28.4 \mathrm{~mm}$ SL and female (below), paratype, MZUSP 109219, $25.3 \mathrm{~mm}$ SL. filaments, or presents only on dorsal fin in S. semiocellatus and $S$. inaequipinnatus, or presents only on anal fin in $S$. chacoensis), and presence (vs. absence) of contact organs on scales of flank in males.

Additionally males of Simpsonichthys brousseaui differ from males of $S$. filamentosus by the color pattern of males, viz., anterior third of body light brown, posterior two-thirds of body dark blue, almost black in the dorsal region, with rows of bright blue spots (vs. overall color pattern in males reddish, with white spots), developed urogenital papillae in males and females (vs. poorly developed urogenital papillae in both sexes), and by the longer dorsal-fin base (33.8-36.2\% SL vs. 29.0-31.1\%), longer head (27.5-28.8\% SL vs. 25.8-26.7\%), lower head (88.691.4\% HL vs. 96.2-107.6\% ), narrower head (55.6-54.6\% SL vs. 63.4-70.7\%), greater number of dorsal-fin rays (21-22 vs. 16-19), and fewer scales in transverse series (8-9vs.11-12).

Females of Simpsonichthys brousseaui differ from females of S. filamentosus by their lower body (30.6-33.3\% SL vs. 34.7$36.8 \%$ ), lower caudal peduncle (11.9-12.6\% SL vs. 13.0-15.0\%), shorter anal-fin base (21.9-27.8\% SL vs. 28.8-31.4\%), longer head (29.2-30.6\% HL vs. 27.3-28.7\%), lower head (78.1-91.6\% HL vs. 93.4-107.2\%), smaller head width (53.0-59.6\% HL vs. 62.7$64.6 \%$ ), smaller eye diameter (29.5-32.3\% SL vs. 33.6-34.9\%), fewer scales in the longitudinal series of scales (23-24 vs. 27 29), and fewer scales in the transverse series of scales (10vs. 12).

Description. Morphometric data in Table 1. Largest specimen examined $34.6 \mathrm{~mm}$ SL. Dorsal profile slightly concave on head, convex from nape to end of dorsal-fin base, approximately straight along caudal peduncle. Ventral profile slightly convex from tip of jaw to origin of caudal peduncle and slightly concave from latter point to uppermost procurrent caudal-fin rays. Body moderately deep, compressed, greatest body depth on vertical slightly ahead to anal-fin origin. Eye positioned on lateral portion of head. Snout blunt. Large number of labial papillae in males. Urogenital papilla cylindrical and long in males, pocket-shaped in females. Tip of both dorsal and anal fins pointed in males with two or three elongated rays; dorsal

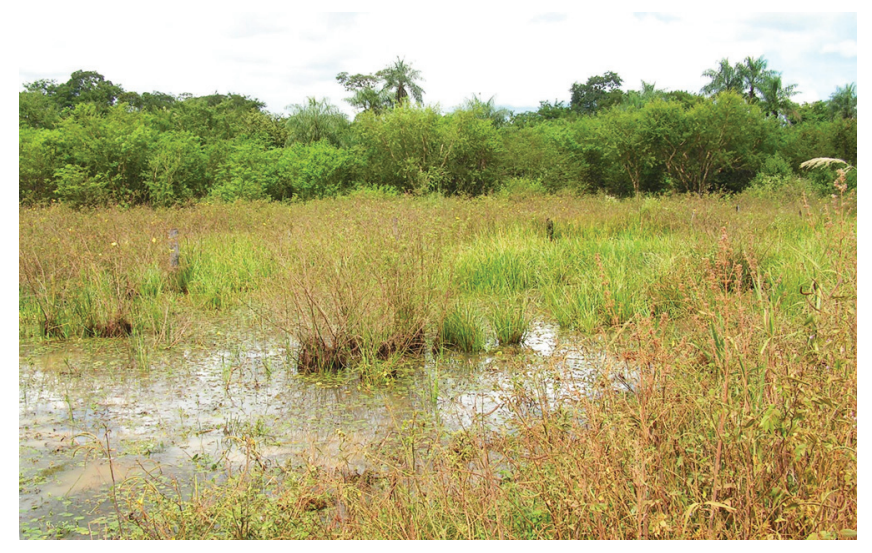

Fig. 2. Temporary pool near río San Pablo, type locality of Spectrolebias brousseaui. 
Table 1. Morphometric and meristic data for the holotype and paratypes of Spectrolebias brousseaui. SD = standard deviation.

\begin{tabular}{|c|c|c|c|c|}
\hline & \multirow{2}{*}{$\frac{\text { Holotype }}{\text { Male }}$} & \multicolumn{2}{|c|}{ Paratypes } & \multirow{2}{*}{ Mean \pm SD } \\
\hline & & Male $n=1$ & Females $\mathrm{n}=5$ & \\
\hline Standard length (mm) & 28.4 & 32.0 & $25.3-34.6$ & $30.7 \pm 4.2$ \\
\hline \multicolumn{5}{|c|}{ Percents of standard length } \\
\hline Body depth & 34.8 & 33.2 & $30.6-33.3$ & $32.2 \pm 1.1$ \\
\hline Caudal peduncle depth & 12.9 & 13.2 & $11.9-12.6$ & $12.3 \pm 0.3$ \\
\hline Pre-dorsal length & 51.5 & 47.2 & $55.8-58.5$ & $57.3 \pm 1.1$ \\
\hline Pre-pelvic length & 39.9 & 36.7 & $41.7-45.9$ & $43.8 \pm 1.6$ \\
\hline Length of dorsal-fin base & 33.8 & 36.2 & $22.1-26.7$ & $24.8 \pm 2.4$ \\
\hline Length of anal-fin base & 39.2 & 43.7 & $21.9-27.8$ & $25.9 \pm 2.3$ \\
\hline Caudal-fin length & 29.6 & 32.6 & $23.4-30.6$ & $27.0 \pm 3.5$ \\
\hline Pectoral-fin length & 21.1 & 22.9 & $17.3-22.7$ & $19.8 \pm 2.5$ \\
\hline Pelvic-fin length & 10.5 & 11.4 & $7.8-12.4$ & $10.8 \pm 2.1$ \\
\hline Head length & 27.5 & 28.8 & $29.2-30.6$ & $29.9 \pm 0.7$ \\
\hline \multicolumn{5}{|c|}{ Percents of head length } \\
\hline Head depth & 88.6 & 91.4 & $78.1-91.6$ & $85.9 \pm 5.7$ \\
\hline Head width & 55.6 & 54.6 & $53.0-59.6$ & $56.0 \pm 2.6$ \\
\hline Snout length & 21.5 & 25.8 & $18.7-23.4$ & $21.4 \pm 2.4$ \\
\hline Lower jaw length & 8.2 & 6.8 & $5.4-7.7$ & $6.8 \pm 0.9$ \\
\hline Eye diameter & 33.6 & 33.8 & $29.5-32.3$ & $30.7 \pm 1.0$ \\
\hline \multicolumn{5}{|c|}{ Counts } \\
\hline Dorsal fin & 21 & 22 & $15(3)-16(2)$ & \\
\hline Caudal fin & 22 & 21 & $20(2)-21(2)$ & \\
\hline Anal fin & 24 & 26 & 21(3)-22(1) & \\
\hline Pelvic fin & 5 & 6 & $05(2)-06(2)$ & \\
\hline Pectoral fin & 12 & 12 & 10(3)-11(1) & \\
\hline \multicolumn{5}{|c|}{ Meristic } \\
\hline Scales in longitudinal series & 27 & 29 & $23(2)-24(3)$ & \\
\hline Scales in transversal series & 8 & 9 & $10(5)$ & \\
\hline Horizontal scales around caudal peduncle & 14 & 16 & $12(1), 14(4)$ & \\
\hline
\end{tabular}

fin in females pointed without filaments; anal fin rounded in females. Very long filamentous rays on tip of dorsal and anal fins in males, tip reaching vertical close to distal margin of caudal fin. Dorsal-fin rays unbranched. Caudal-fin subtruncate. Pectoral fins elliptical.

Posterior margin of each pectoral fin reaching vertical between base of fifth to seventh anal-fin rays in males, and between base of first to second anal-fin rays in females. Tip of each pelvic fin reaching base of third to fifth anal-fin rays in males, and base of first to second anal-fin rays in females. Pelvic-fin bases separated by interspace about equal to width of pelvic-fin base. Dorsal-fin origin on vertical line through base of fourth to fifth anal-fin rays.

Dorsal-fin rays 21-22 in males, $15-16$ in females; anal-fin rays 24-26 in males, 21-22 in females; caudal-fin rays 20-22; pectoral-fin rays 10-12; pelvic-fin rays 5-6. Frontal squamation E-patterned; E-scales overlapping medially; no scale anterior to G-scale; supraorbital scales absent. Longitudinal series of scales 23-29; transverse series of scales 8-10; scale rows around caudal peduncle 12-16. Contact organ present on flank and absent on pectoral fin in males.

Coloration. Males. Head and trunk to vertical line passing through anal fin origin light brown. Posterior two-thirds of body dark blue, almost black in dorsal region, including unpaired fins. Trunk at height of beginning of dorsal fin with row of bright blue spots, each with diameter of approximately half of pupil, aligned vertically up to caudal peduncle. Dorsal region darker than ventral region.
Tip of jaw darkened. Dorsal fin with same color pattern of body, spots of smaller size than those on body. Anal fin with same pattern of background color of body and with same iridescent blue spots, but randomly distributed. Black Filaments on dorsal and anal fins. Anterior region of caudal fin dark blue, gradually becoming translucent towards edge of caudal fin. Caudal fin with fewer iridescent blue spots than body, concentrated on its dark portion. Hyaline pectoral fin. Dark pelvic fin with iridescent blue spots on center. Black bar vertically crossing eye.

Females. Side of body light brown, with 10-11 dark gray bars; one to three black spots on mid-body. Sides of head light brown, opercular region pale greenish golden. Iris light yellow, with dark vertical brown bar across center of eye. Fins hyaline, with dorsal and anal-fin rays light brown.

Distribution. Known from the type locality in río San Pablo basin, a tributary of the río Mamoré, Departamento Santa Cruz, Bolivia.

Habitat. The type locality lies at the plateau area (316 m.a.s.l.), just southwest of Llanos de Mojos, which occupy much of the río Mamoré basin in Bolivia (see Loubens et al., 1992). Water temperature at the surface of the pool was $31^{\circ} \mathrm{C}$, while at the depth of $1 \mathrm{~m}, 22^{\circ} \mathrm{C}$. In the marginal area of the pool, at the depth of $15 \mathrm{~cm}$, water temperature was $35^{\circ} \mathrm{C}$. Only small specimens of Trigonectes sp. were collected in marginal areas. Specimens of Simpsonichthys brousseaui were collected in the deepest areas, at about $1 \mathrm{~m}$ deep. The pool presented 
dark water, pH 6.8 and water hardness 80 ppm. Other fish species collected syntopically were Trigonectes sp.

Etymology. The specific name is in honor to Roger D. Brousseau, discoverer of the species.

\section{Discussion}

The color pattern of the body, brown from head to anterior one-third of the body, and becoming gradually dark blue from the line that passes through the anal fin origin, is an autapomorphy of Spectrolebias brousseaui within the genus Spectrolebias.

In the phylogeny proposed by Costa (2006), Spectrolebias filamentosus was considered the sister species to $S$. semiocellatus, sharing five unambiguous apomorphic characters, one of which is easily visible externally and also present in $S$. brousseaui. The ventral profile of the head is angular, in which there is a prominent flap of thickened tissue at level of the angular-articular bone, the dorsal and ventral profiles of the caudal penducle usually are straight, sometimes weakly concave, the laminar extension is reduced in S. filamentosus and S. semiocellatus, the fifth ceratobranchial is slender and their anterior and posterior portions form an angle of $145^{\circ}$ and in $S$. semiocellatus and $S$. filamentosus there are 15-21 rays in dorsal-fin and the dorsal-fin origin is between the neural spines of vertebrae 10 and 14.

However, Spectrolebias brousseaui is more similar to $S$. filamentosus by sharing the presence of contact organs on the flank, which according to Costa (2006) would be a reversal within the subgenus Spectrolebias, the presence of a space between the pelvic fins, and the presence of elongated filaments on the dorsal and anal fins in males.

The putative phylogenetic proximity between these two species is consistent with the closeness of their geographical distributions, since both occur in the hydrographic basin of the río San Pablo. However, the type locality of Spectrolebias brousseaui is located on the right bank, while S. filamentosus occurs on the left bank, and at a distance of $368 \mathrm{~km}$ in a straight line to the northwest, which may suggest that other populations may occur, or even other still unknown species of this genus in the intervening area.

\section{Acknowledgments}

Thanks are due to Roger D. Brousseau for the donation of specimens, Oscar A. Shibatta for support at the laboratory, and Flávio C.T. Lima for useful suggestions to the manuscript.

\section{Literature Cited}

Amato, L. H. 1986. Seis especies nuevas del genero Cynolebias Steindachner, 1876, de Uruguay y Paraguay (Cyprinodontiformes, Rivulidae). Comunicaciones Zoologicas Del Museo de Historia Natural de Montevideo, 11: 1-27.
Costa, W. J. E. M. 1995. Pearl killifishes - the Cynolebiatinae: systematics and biogeography of a neotropical annual fish subfamily. Neptune City, TFH, 128p.

Costa, W. J. E. M. 1998. Phylogeny and classification of Rivulidae revisited: origin and evolution of annualism and miniaturization in rivulid fishes (Cyprinodontiformes: Aplocheiloidei). Journal of Comparative Biology, 3: 33-92.

Costa, W. J. E. M. 2006. Descriptive morphology and phylogenetic relationship among species of the Neotropical annual killifish genera Nematolebias and Simpsonichthys (Cyprinodontiformes: Aplocheiloidei: Rivulidae). Neotropical Ichthyology, 4: 1-26.

Costa, W. J. E. M. 2007. Taxonomic revision of the seasonal South American killifish genus Simpsonichthys (Teleostei: Cyprinodontiformes: Aplocheiloidei: Rivulidae). Zootaxa, 1669: $1-134$.

Costa, W. J. E. M. 2010. Historical biogeography of cynolebiasine annual killifishes inferred from dispersal-vicariance analysis. Journal of Biogeography, 2010: 98-110.

Costa, W. J. E. M. \& D. T. B. Nielsen. 1997. A new genus and species of annual fish (Cyprinodontiformes: Rivulidae) from the Araguaia basin, central Brazil. Ichthyological Exploration of Freshwaters, 7: 257-265.

Costa, W. J. E. M., S. Barrera \& J. Sarmiento. 1997. Simpsonichthys filamentosus, une nouvelle espèce des Llanuras Benianas, bassin du Rio Mamoré, Bolivia. Revue Française d'Aquariologie, 24: 83-86.

Costa, W. J. E. M. \& D. T. B. Nielsen. 2003. Simpsonichthys reticulatus $\mathrm{n}$. sp. (Cyprinodontiformes: Rivulidae) a new annual fish from the Rio Xingu floodplains, Brazilian Amazon. Aqua Journal of Ichthyology and Aquatic Biology, 7: 119-122.

Costa, W. J. E. M. \& G. C. Brasil. 2008. Simpsonichthys inaequipinnatus, a new seasonal killifish from the Tocantins River basin, Brazil (Cyprinodontiformes, Rivulidae). Ichthyological Exploration of Freshwaters, 3: 245-248.

Hoedeman, J. J. 1958. The frontal scalation pattern in some groups of toothcarps. Bulletin of Aquatic Biology, 1: 23-28.

Lazara, K.1991. Cynolebias lacortei, Cynolebias costai, and Cynolebias aruana: three new species of cloud fish from Brazil (Teleostei: Cyprinodontiformes: Rivulidae). Journal of the American Killifish Association, 23: 139-152.

Loubens, G., L. Lauzanne \& B. Le Guennec. 1992. Les milieux aquatiques de la région de Trinidad (Beni: Amazonie bolivienne). Revue d'Hydrobiologie Tropical, 25: 3-21.

Myers, G. S. 1952. Annual fishes. Aquarium Journal, 23: 125-141.

Wourms, J. P. 1972. The developmental biology of annual fishes III. Pre-embryonic and embryonic diapause of variable duration in the eggs of annual fishes. Journal of Experimental Zoology, 182: $389-414$.

Submitted January 25, 2012

Accepted November 26, 2012 by Paulo H. F. Lucinda

Published March 31, 2013 